COMPARATIVE CHARACTERIZING ANALYSIS OF ESSENTIAL OILS OF FIVE SPECIES OF THE GENUS BACCHARIS, COLLECTED IN THREE COUNTIES AT LA PAZ, BOLIVIA

\section{ANÁLISIS COMPARATIVO DE CARACTERIZACIÓN DE ACEITES ESENCIALES DE CINCO ESPECIES DEL GÉNERO BACCHARIS, COLECTADAS EN TRES CONDADOS DE LA PAZ, BOLIVIA}

Full original article

Received 12092019

Accepted 04072020

Published 04302020

Vol. 37, No.1, pp. 01-11, Ene./Abr.2020

Revista Boliviana de Química

37(1), 01-11, Jan./Apr. 2020

Bolivian Journal of Chemistry

DOI : $10.34098 / 2078-3949.37 .1 .1$

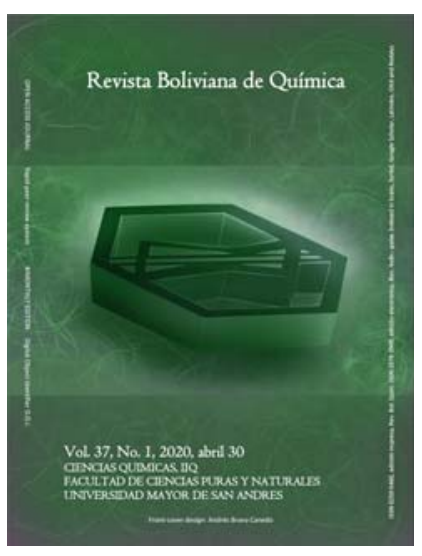

Silvia E. Ramos Paredes, Santiago Tarqui, Ever Gutiérrez†, Eduardo Oña, Yonny Flores, Giovanna R. Almanza*

Laboratorio de Bioorgánica, Instituto de Investigaciones Químicas IIQ, Carrera de Ciencias Químicas, Facultad de Ciencias Puras y Naturales FCPN, Universidad Mayor de San Andrés UMSA, P.O. Box 303, Calle Andrés Bello s/n, Ciudad Universitaria Cota Cota, phone +59122792238, La Paz, www.iiq.umsa.bo

Keywords: Monoterpenes, Sesquiterpenes, Essential oil, Baccharis, B. boliviensis, B. densiflora, B. latifolia, B. papilllosa, B. tola.

Palabras clave: Monoterpenos, Sesquiterpenos, Aceite esencial, Baccharis, B. boliviensis, B. densiflora, B. latifolia, B. papillosa, B. tola.

\title{
ABSTRACT
}

The essential oils from the leaves of five species of the genus Baccharis, namely Baccharis boliviensis, $B$. densiflora, B. latifolia, B. papilllosa and B. tola collected in three counties, Cota-Cota, Mecapaca and Carpani at La Paz, Bolivia, were extracted using hydrodistillation procedures and subsequently analyzed by GC/MS. Four of the species were collected in two places of the La Paz valley, in order to establish the changes in composition in function of the place of origin. B. densiflora was collected only in one place because of the scarcely availability of the plant material in the other collecting sites. The essential oils obtained from the five species are composed mainly by monoterpenes, and a less percentage of sesquiterpenes, in addition, few non terpenic components were detected. The only exception was B. latifolia that showed almost the same amount of sesquiterpenes and monoterpenes. The samples of a same species collected at two different sites showed, as a rule, similar GC/MS profiles with the exception of $B$. tola that showed higher amounts of hydrocarbon sesquiterpenes and lower quantities of cyclic monoterpenes from Carpani to Cota Cota. The analysis of the identified compounds showed that some of them were present in good quantities in all the samples of essential oils examined, like for instance, $\beta$-myrcene, D-limonene, $\alpha$ thujene, D- $\alpha$-pinene, sabinene, L- $\beta$-pinene and $\alpha$-muurolene. 
Los aceites esenciales de las hojas de cinco especies del género Baccharis, a saber, Baccharis boliviensis, $B$. densiflora, B. latifolia, B. papilllosa y B. tola, recogidas en tres condados, Cota-Cota, Mecapaca y Carpani en La Paz, Bolivia, se extrajeron mediante procedimientos de hidrodestilación y posteriormente se analizaron por GC/MS. Cuatro de las especies fueron recolectadas en dos lugares del valle de La Paz, a fin de establecer los cambios en la composición en función del lugar de origen. B. densiflora se recolectó solo en un lugar debido a la escasa disponibilidad del material vegetal en los otros sitios de recolección. El aceite esencial obtenido de las cinco especies está compuesto principalmente por monoterpenos, y un menor porcentaje de sesquiterpenos, además, se detectaron pocos componentes no terpénicos. La única excepción fue B. latifolia que mostró casi la misma cantidad de sesquiterpenos y monoterpenos. Las muestras de una misma especie recolectadas en dos sitios diferentes mostraron, por regla general, perfiles GC/MS similares con la excepción de B. tola que mostró mayores cantidades de sesquiterpenos hidrocarbonados y menor cantidad de monoterpenos cíclicos de Carpani a Cota Cota. El análisis de los compuestos identificados mostró que algunos de ellos estaban presentes en buenas cantidades en todas las muestras de aceites esenciales examinadas, como por ejemplo, $\beta$-mirceno, D-limoneno, $\alpha$-tujeno, D- $\alpha$-pineno, sabineno, L- $\beta$-pineno y $\alpha$-muuroleno.

\section{INTRODUCTION}

Baccharis is the largest genus in the Asteraceae family, with more than 500 species distributed in all Americas [1], with wider incidence in Brazil, Bolivia, Argentina, Colombia, Chile and Mexico [2]. The five species employed in the present investigation proceeded form the valley of La Paz, Bolivia: Baccharis latifolia, B. densiflora, B. boliviensis, B. tola and B. papillosa, all of them are well-reputed in folk Bolivian medicine for the treatment of rheumatism, liver diseases, infectious problems, wounds and ulcers $[1,3,4]$; they were previously reported by our research group for their flavonoid contents [5-9]. The first four were collected in two places of the La Paz valley at different dates, to see the changes in composition due of the change of environment. B. densiflora was collected only in one place because of the scarcely availability of the plant material in the other collecting sites

The essential oils are the odoriferous principles found in several parts of the plant, they have the function of adapting the plant organism to the environment, chemically they are complex and highly variable mixtures of constituents that belong, almost exclusively, to two groups characterized by different biogenetic origins: the group of terpenoids and the group of aromatic compounds derived from phenylpropane, much less frequent [10]. Biologically, these compounds act in the defense of the plant against the attack of predators, attraction of pollination agents, protection against water loss and as inhibitors of germination [11,12]. Economically, they're in food, cosmetic and cleaning products industries, also in medicine thanks to their many therapeutic properties. However, despite of their many beneficial characteristics, toxic effects of those substances can't be discarded [13].

Their presence depends of several different factors, such as: soil conditions, geographic location, vegetative cycle and the process of obtaining $[10,14,15]$.

There are several studies of essential oils from Baccharis species, reporting more than one hundred constituents in some Latin American species [16-18]. The compounds that appear most frequently in these species are: sabinene, $\alpha$ - and $\beta$-pinene, myrcene, limonene, $\delta$-cadinene, nerolidol, terpinen-4-ol, $\alpha$-tujeno, $\alpha$-fellandreno, $\beta$-Cimeno and elemol. In particular, Bolivian researchers identified about 100 compounds in the essential oil of $B$. latifolia, from specimens collected in three locations in Cochabamba, where the major monoterpenes were $\alpha$-pinene, limonene, $\beta$ tujeno, pinocarvenol, verbenol, mirtenol, mirtenal and carvone, in addition to important sesquiterpenes such as germacrene D and ledol [19], among others.

\section{RESULTS AND DISCUSSION}

The essential oils of five Baccharis species of high bioavailability in the Valley of La Paz-Bolivia, were obtained. The oils were extracted by hydrodistillation technique, with yields among 0.08 and $0.18 \%$ (Table 1). From the first four species the oils were obtained from two collection sites with different environmental characteristics. The collections were done in the same phenological stage and the same period of the year to have data about the effect of the environmental change on the production of essential oils. From Baccharis densiflora, the study could not be carried out at two collection sites because there were not two sites with a significant presence of this species among the collection sites.

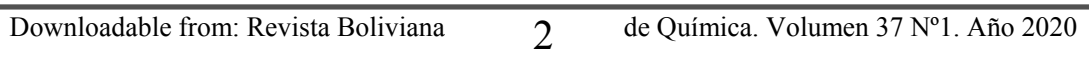

http://www.bolivianchemistryjournal.org, http://www.scribd.com/bolivianjournalofchemistry 
Table 1. Details of the studied Baccharis species from La Paz, Bolivia

\begin{tabular}{lllllllc}
\hline $\mathbf{N}^{\circ}$ & Species & Collecting site & $\begin{array}{l}\text { Height } \\
\text { masl }\end{array}$ & $\begin{array}{l}\text { Collecting } \\
\text { date }\end{array}$ & Period & $\begin{array}{l}\text { Phenological } \\
\text { Stage }\end{array}$ & $\begin{array}{c}\text { Oil } \\
\text { Yield \% }\end{array}$ \\
\hline 1 & B. papillosa & Cota Cota & 3422 & $15 / 01 / 19$ & Wet & Flowering & 0.14 \\
2 & B. papillosa & Carpani & 4012 & $15 / 11 / 18$ & Wet & Flowering & 0.16 \\
3 & B. tola & Cota Cota & 3427 & $07 / 06 / 18$ & Dry & Maturation & 0.11 \\
4 & B. tola & Carpani & 4011 & $04 / 06 / 18$ & Dry & Maturation & 0.12 \\
5 & B. latifolia & Cota Cota & 3415 & $15 / 05 / 18$ & Dry & Maturation & 0.18 \\
6 & B. latifolia & Carpani & 3361 & $04 / 06 / 18$ & Dry & Maturation & 0.15 \\
7 & B. boliviensis & Cota Cota & 3423 & $15 / 01 / 19$ & Wet & Flowering & 0.13 \\
8 & B. boliviensis & Mecapaca & 2986 & $15 / 11 / 18$ & Wet & Flowering & 0.10 \\
9 & B. densiflora & Carpani & 3365 & $15 / 11 / 18$ & Wet & Flowering & 0.08 \\
\hline
\end{tabular}

Below are the tables with the results of the analyses obtained in the GC/MS equipment of each oil, divided into types of compounds and by species

Table 2. Percentage composition of the essential oils of Baccharis papillosa from two collecting sites

\begin{tabular}{|c|c|c|c|c|c|c|c|}
\hline $\mathbf{N}^{\mathbf{0}}$ & Compound & $\begin{array}{c}\text { Area \% } \\
\text { Cota Cota }\end{array}$ & $\begin{array}{l}\text { Area \% } \\
\text { Carpani }\end{array}$ & $\mathbf{N}^{\mathbf{0}}$ & Compound & $\begin{array}{c}\text { Area \% } \\
\text { Cota Cota }\end{array}$ & $\begin{array}{l}\text { Area \% } \\
\text { Carpani }\end{array}$ \\
\hline & \multicolumn{3}{|l|}{ Acyclic monoterpenes } & & \multicolumn{3}{|c|}{ Hydrocarbon sesquiterpenes } \\
\hline 1 & 6-Myrcene & 4,46 & 4,10 & 18 & Copaene & 0,78 & 0,85 \\
\hline 2 & E-Cis-Ocimene & 1,30 & 0,53 & 19 & Caryophyllene & 0,17 & $\mathrm{Nd}$ \\
\hline 3 & Cis-Geranyl acetate & 0,29 & $\mathrm{Nd}$ & 20 & $\alpha$-Caryophyllene & 0,37 & 0,19 \\
\hline 4 & Geranyl acetate & 0,54 & 0,85 & 21 & $\alpha$-Cubebene & 0,80 & 12,45 \\
\hline \multirow[t]{2}{*}{5} & Neryl acetate & $\mathrm{Nd}$ & 0,35 & 22 & Guaia 6,9-diene & 1,23 & 1,02 \\
\hline & \multicolumn{3}{|l|}{ Monocyclic monoterpenes } & 23 & y-Muurolene & 1,17 & 4,16 \\
\hline 6 & Pesudolimenene & 0,14 & 0,24 & 24 & D-Germacrene & 0,36 & 0,67 \\
\hline \multirow{2}{*}{$\begin{array}{l}7 \\
8\end{array}$} & \multirow{2}{*}{$\begin{array}{l}\alpha-\text { Phellandrene } \\
1,3,5 \text { cyclopentatriene, } 3,7,7 \\
\text { trimethyl }\end{array}$} & 1,45 & 1,64 & 25 & $\alpha$ - Guaiene & 1,08 & $\mathrm{Nd}$ \\
\hline & & 0,61 & 1,18 & 26 & $y$-Elemene & 2,97 & 1,21 \\
\hline 9 & y -Terpinene & 1,43 & 0,84 & 27 & $\alpha$-Muurolene & 3,26 & 4,14 \\
\hline 10 & Terpinen-4-O1 & 0,56 & 0,52 & 28 & $\gamma$-Amorphene & 9,57 & 0,98 \\
\hline \multirow[t]{2}{*}{11} & Isopropyl Benzoate & $\mathrm{Nd}$ & 0,21 & 29 & $\alpha$-Copaene & 0,31 & $\mathrm{Nd}$ \\
\hline & \multicolumn{3}{|l|}{ Bicyclic monoterpenes } & 30 & Cubebene & 0,72 & 0,49 \\
\hline 12 & $\alpha$-Thujene & 10,30 & 7,40 & 31 & Germacrene B & 0,49 & $\mathrm{Nd}$ \\
\hline 13 & D- $\alpha$-Pinene & 23,62 & 20,37 & 32 & $\alpha$-Ylangene & $\mathrm{Nd}$ & 1,44 \\
\hline 14 & Sabinene & 4,13 & 2,92 & 33 & $\beta$-Eudesmane & $\mathrm{Nd}$ & 0,50 \\
\hline 15 & L-\&-Pinene & 5,85 & 5,39 & & Oxygenated sesquite & & \\
\hline 16 & $(+) 4$ Carene & 0,82 & 0,48 & 34 & $(+/-)$ Trans Nerolidol & 0,66 & $\mathrm{Nd}$ \\
\hline \multirow[t]{3}{*}{17} & $(+) 2$ Carene & 0,45 & 0,35 & 35 & Di-epi-1, 10 cubenol & 1,86 & 0,28 \\
\hline & $\begin{array}{l}\text { Total percentage } \\
\text { monoterpenes }\end{array}$ & 55,95 & 47,37 & 36 & Tau muurolol & 1,61 & $\mathrm{Nd}$ \\
\hline & \multicolumn{3}{|l|}{ Others } & 37 & $\alpha$-Cadinol & $\mathrm{Nd}$ & 1,85 \\
\hline 38 & $\begin{array}{l}1,3,7 \text {, Nonatriene } 4,8 \text { dimethyl } \\
\text { (E) }\end{array}$ & 0,21 & 0,22 & & $\begin{array}{l}\text { Total percentage } \\
\text { sesquiterpenes }\end{array}$ & 27,41 & 30,23 \\
\hline 39 & Benzyl isobutanoate & $\mathrm{Nd}$ & 0,36 & & & & \\
\hline \multirow[t]{2}{*}{40} & Cinnamyl Butyrate & $\mathrm{Nd}$ & 0,63 & & Not Identified & 16,41 & 21,17 \\
\hline & Total percentage others & $\mathbf{0 , 2 1}$ & 1,21 & & & & \\
\hline
\end{tabular}

The essential oil of Baccharis papillosa was obtained in two collecting sites of La Paz: University campus of Cota Cota, a metropolitan region, and Carpani a rural community near of La Paz city. Both samples were taken in wet station and flowering phenological stage (Table 1), giving a yield of 0,14\% (Cota Cota) and 0,16\% (Carpani). The GC/MS analysis (Table 2) show a similar profile for both with monoterpenes as major components $55,95 \%$ (Cota Cota) and 47,37\% (Carpani), followed by sesquiterpenes 27,41\% (Cota Cota) and 30,23\% (Carpani). A total

Downloadable from: Revista Boliviana 3 de Química. Volumen 37 Nº1. Año 2020


Silvia E. Ramos Paredes et a1. RBQ Vol. 37, No.1, pp. 01-11, 2020

of 40 compounds were identified, constituting 83,57\% of total essential oil obtained in Cota Cota and 78,81\% in Carpani. The main compounds of the essential oils of both samples were the monoterpenes: $\beta$-myrcene, $\alpha$-thujene, D $\alpha$-pinene, sabinene and L- $\beta$-pinene. The major difference between both samples was in the sesquiterpenes where we can see the $\alpha$-cubebene as the main component in the sample from Carpani $(12,45 \%)$ but not in Cota Cota $(0,80 \%)$, and the $\gamma$-amorphene as the main component in the sample from Cota Cota $(9,57 \%)$ but not in Carpani $(0,98 \%)$. Therefore, the difference in the environmental conditions of both places affect mainly the biosynthesis of hydrocarbon sesquiterpenoids.

Table 3. Percentage composition of the essential oils of Baccharis tola from two collecting sites

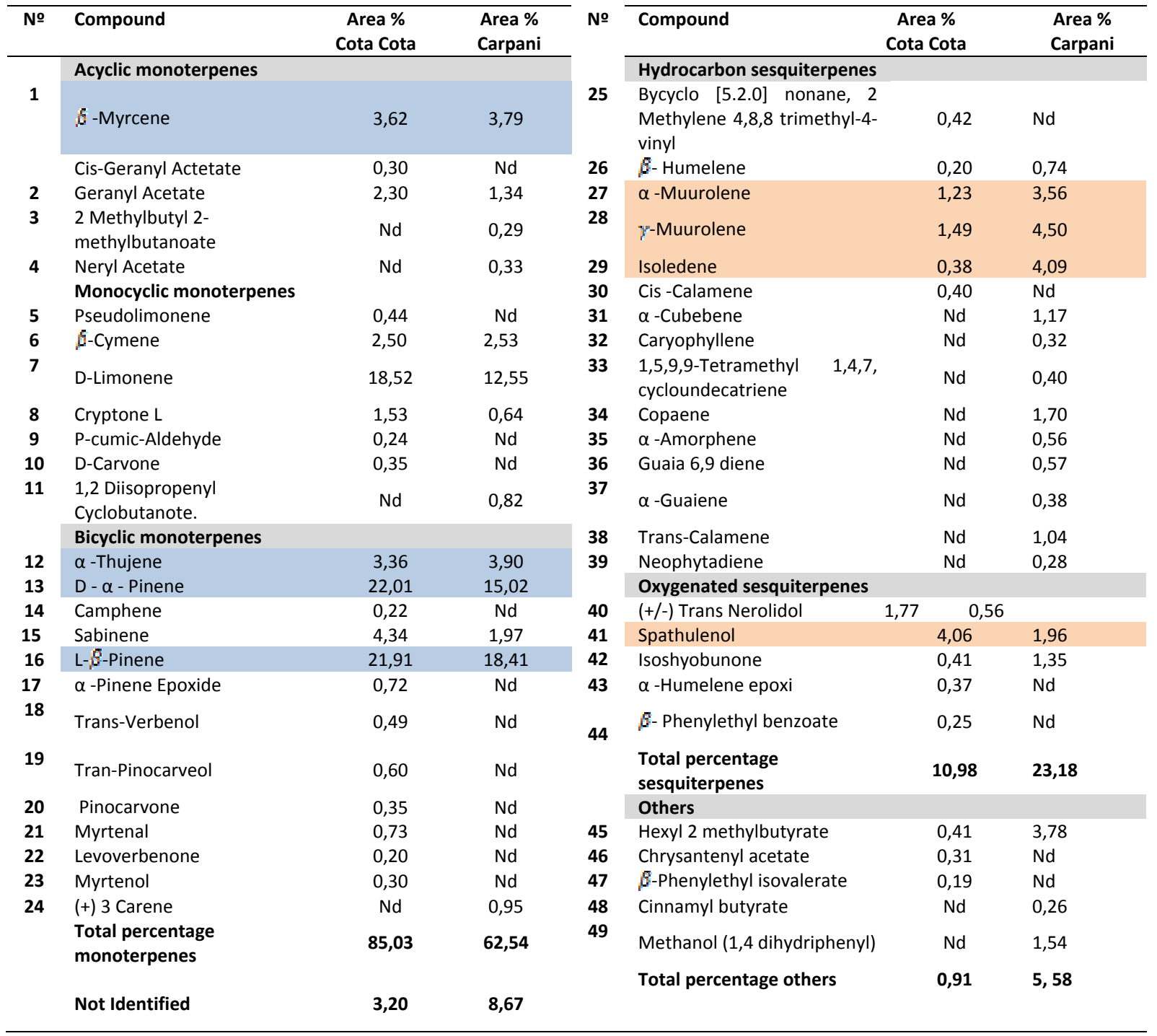

The essential oil of Baccahris tola was obtained in the same collecting sites than B. papillosa: Cota Cota and Carpani, but in the dry season, when the plants are in maturation phenological stage (Table 1). The oil yields were very similar $0,11 \%$ (Cota Cota) and $0,12 \%$ (Carpani) but the GC/MS analysis (Table 3) shows bigger differences than in B. papillosa. Both oils have monoterpenes as main components and sesquiterpenes as second major metabolites, but the sample collected in Cota Cota has $85,03 \%$ of monoterpenes and $10,98 \%$ of sesquiterpenes, while the sample from Carpani has 62,54\% of monoterpenes and 23,19\% of sesquiterpenes. So, the environmental conditions in Carpani seems to stimulate the production of sesquiterpenes instead of some monoterpenes. The main monoterpenes in both samples were: $\beta$-myrcene, D-limonene, $\alpha$-thujene, D- $\alpha$-pinene and L- $\beta$-pinene, in general with 
Silvia E. Ramos Paredes et al. RBQ Vol. 37, No.1, pp. 01-11, 2020

bigger concentration in the oil obtained of the sample from Cota Cota. Respect of sesquiterpenes the main components were: $\alpha$-muurolene, $\gamma$-muurolene, isoledene and spathulenol, in the first three there were major production in Carpani than in Cota Cota, and in the last one there was major production in Cota Cota. In total 49 compounds were identified representing more than $90 \%$ of the analyzed oils from B. tola.

Table 4. Percentage composition of the essential oils of Baccharis latifolia from two collecting sites

\begin{tabular}{|c|c|c|c|c|c|c|c|}
\hline № & Compound & $\begin{array}{c}\text { Area \% } \\
\text { Cota Cota }\end{array}$ & $\begin{array}{l}\text { Area \% } \\
\text { Carpani }\end{array}$ & № & Compound & $\begin{array}{c}\text { Area \% } \\
\text { Cota Cota }\end{array}$ & $\begin{array}{l}\text { Area \% } \\
\text { Carpani }\end{array}$ \\
\hline & Acyclic monoterpenes & & & & Hydrocarbon sesquiter & enes & \\
\hline 1 & 8-Myrcene & 3,81 & 3,37 & 25 & $\alpha$-Cubebene & 0,29 & $\mathrm{Nd}$ \\
\hline 2 & $\beta$-Cis-Ocimene & 2,05 & 1,88 & 26 & Caryophyllene & 0,79 & 0,78 \\
\hline \multirow[t]{2}{*}{3} & Geranyl acetate & 0,54 & 0,38 & 27 & Humelene & 0,53 & 0,65 \\
\hline & Monocyclic monoterpenes & & & 28 & Cadina 3,5 diene & 0,39 & 0,45 \\
\hline 4 & $\beta$-Cymene & 2,27 & 2,50 & 29 & $\gamma$-Muurolene & 1,88 & 2,03 \\
\hline 5 & D-Limonene & 2,53 & 2,01 & 30 & $\beta$-Copaene & 0,41 & $\mathrm{Nd}$ \\
\hline 6 & $\gamma$-terpinene & 0,86 & 0,97 & 31 & D-Germacrene & 0,49 & 0,44 \\
\hline \multirow[t]{2}{*}{7} & Para Cymen 8 Ol & 0,30 & 0,36 & 32 & $\alpha$-Muurolene & 4,44 & 4,56 \\
\hline & Bicyclic monoterpenes & & & 33 & $\gamma$-Cadinene & 5,91 & 5,31 \\
\hline 8 & $\alpha$-Thujene & 7,99 & 6,18 & 34 & 1 (10) Aromadendrene & 12,05 & $\mathrm{Nd}$ \\
\hline 9 & D- $\alpha$-Pinene & 8,57 & 6,27 & 35 & $\alpha$-Cadinene & 1,13 & 1,18 \\
\hline 10 & (+) Sabinene & 4,31 & 3,35 & 36 & $(-) \beta$-Cadinene & 1,27 & 10,23 \\
\hline 11 & L- $\theta$-Pinene & 5,18 & 4,30 & 37 & Copaene & $\mathrm{Nd}$ & 1,10 \\
\hline 12 & $(+) 4$ Carene & 3,19 & 3,47 & & Oxygenated sesquiterp & nes & \\
\hline \multirow[t]{8}{*}{13} & Eucalyptol & $\mathrm{Nd}$ & 0,77 & 38 & 6 -Epishyobunone & 1,99 & 2,43 \\
\hline & $\begin{array}{l}\text { Total percentage } \\
\text { monoterpenes }\end{array}$ & 41,6 & 35,81 & 39 & Cubebol & 0,72 & 0,86 \\
\hline & & & & 40 & Germacrene D-4-OI & 3,46 & 3,54 \\
\hline & Not Identified & 17,43 & 23,23 & 41 & Caryophyllene oxide & 0,57 & 0,45 \\
\hline & & & & 42 & $\alpha$ - Cadinol & 3,55 & 4,56 \\
\hline & & & & 43 & (-) - Oplopanone & 1,12 & 0,82 \\
\hline & & & & 44 & $\alpha$ - Bisababol & $\mathrm{Nd}$ & 1,57 \\
\hline & & & & & $\begin{array}{l}\text { Total percentage } \\
\text { sesquiterpenes }\end{array}$ & 40,99 & 40,96 \\
\hline
\end{tabular}

The samples of Baccharis latifolia also were collected in the same sites: Cota Cota and Carpani in dry season. The oil yields were a little bigger than those of the other Baccharis studied, 0,18\% (Cota Cota) and 0,15\% (Carpani). The GC/MS analysis (Table 4) showed a different profile than those of the other Baccharis, with a similar percentage of monoterpenes and sesquiterpenes (Cota Cota, monoterpenes 41,6\% and sesquiterpenes 40,99\%; Carpani, monoterpenes $35,81 \%$ and sesquiterpenes $40,96 \%$ ). So, this was the species with major production of sesquiterpenes. The composition of the essential oils from both sites was very similar with the exception of sesquiterpenes 1(10)-aromadendrene which represents $12,05 \%$ in the oil from Cota Cota and it was not identified in the oil from Carpani, and (-) $\beta$-cadinene which represents $1,27 \%$ in the oil from Cota Cota and $10,23 \%$ in the oil from Carpani. The major identified components were: $\beta$-myrcene, $\alpha$-thujene, $D$ - $\alpha$-pinene, $(+)$ sabinene, L- $\beta$-pinene, $(+)$ 4-carene, $\alpha$-muurolene, $\gamma$-cadinene, 1 (10)-aromadendrene, $\beta$-cadinene and germacrene D-4-ol, among 44 compounds identified in the oil from B. latifolia, which represents $82,49 \%$ of the essential oil obtained from Cota Cota and $76,77 \%$ from Carpani.

The samples of B. boliviensis were collected in the University Campus of Cota Cota (3300 m.a.s.l.) and in Mecapaca (3000 m.a.s.1.), a different site wetter and at lower meters above sea level than the other two sites. The oil yield of the sample from Cota Cota $(0,13 \%)$ was higger than that of Mecapaca $(0,10 \%)$. The GC/MS profile of the essential oil from both species were very similar with a clear predominance of monoterpenes: $88,32 \%$ (Cota Cota) and $91,12 \%$ (Mecapaca). A total of 46 compounds were identified representing more than $95 \%$ of the analyzed oil from $B$. boliviensis. The main components in both samples were: $\beta$-myrcene, geranyl acetate, $\beta$-cymene, $D$ limonene, $\alpha$-thujene, D- $\alpha$ - pinene, sabinene and L- $\beta$-pinene, showing some quantitative differences especially in geranyl acetate, D-limonene and sabinene. 
Silvia E. Ramos Paredes et al. RBQ Vol. 37, No.1, pp. 01-11, 2020

Finally, Baccharis densiflora (Syn B. pentlandii) was collected only in Carpani. Its essential oil yield was the lowest $(0,08 \%)$ and its GC/MS profile was the simplest, with a total of 17 compounds identified.

Table 5. Percentage composition of the essential oils of Baccharis boliviensis from two collecting sites

\begin{tabular}{|c|c|c|c|c|c|c|c|}
\hline \multirow[t]{2}{*}{ № } & Compound & $\begin{array}{c}\text { Area \% } \\
\text { Cota Cota }\end{array}$ & $\begin{array}{c}\text { Area \% } \\
\text { Mecapaca }\end{array}$ & \multirow[t]{2}{*}{ № } & \multicolumn{2}{|c|}{$\begin{array}{c}\text { Area \% } \\
\text { Cota Cota }\end{array}$} & \multirow[t]{2}{*}{$\begin{array}{c}\text { Area \% } \\
\text { Mecapaca }\end{array}$} \\
\hline & Acyclic monoterpenes & & & & Hydrocarbon sesquiterpenes & & \\
\hline 1 & Q-Myrcene & 5,81 & 4,59 & 28 & $\alpha$-Cubebene & 0,30 & 0,76 \\
\hline 2 & Trans- $\beta$-Ocimene & 3,28 & 0,79 & 29 & Aromandrene & 0,20 & $\mathrm{Nd}$ \\
\hline 3 & G-Cis Ocimene & 0,96 & $\mathrm{Nd}$ & 30 & $\alpha$-Ylangene & 0,33 & $\mathrm{Nd}$ \\
\hline 4 & n-Hexyl butanoate & 0,61 & 0,37 & 31 & $\alpha$-Guaiene & 0,32 & $\mathrm{Nd}$ \\
\hline 5 & Cis Geranyl acetate & 3,26 & 0,89 & 32 & $\alpha$-Muurolene & 0,28 & 0,47 \\
\hline \multirow[t]{2}{*}{6} & Geranyl acetate & 5,07 & 2,43 & 33 & $\gamma$-Amorphene & 0,27 & $\mathrm{Nd}$ \\
\hline & Monocyclic monoterpenes & & & 34 & $\alpha$-Copaene & $\mathrm{Nd}$ & 0,46 \\
\hline 7 & $\alpha$-Phellandrene & 1,37 & $\mathrm{Nd}$ & 35 & $\gamma$-Muurolene & $\mathrm{Nd}$ & 0,91 \\
\hline 8 & E-Cymene & 10,38 & 8,63 & 36 & & & \\
\hline 9 & D-Limonene & 17,37 & 29,57 & & & & \\
\hline 10 & Terpinen-4-OI & 0,46 & 0,20 & & Oxygenated sesquiterpenes & & \\
\hline 11 & Cryptone L & 0,60 & 0,85 & 37 & D-Viridiflorol & 0,41 & $\mathrm{Nd}$ \\
\hline 12 & P-Cymen-8-OI & 0,31 & 0,25 & 38 & $\begin{array}{l}\text { Butanoic Acid, 2-Methyl-, 3,7- } \\
\text { Dimethyl-2,6-Octadienyl } \\
\text { Esther, (E) }\end{array}$ & 2,01 & $\mathrm{Nd}$ \\
\hline 13 & $\begin{array}{l}\text { Cyclohexanone, 2-(1-methyl- } \\
\text { 2-oxopropyl) }\end{array}$ & 1,11 & $\mathrm{Nd}$ & 39 & Tau Muurolol & 0,28 & $\mathrm{Nd}$ \\
\hline \multirow[t]{2}{*}{14} & (-) Carvone & $\mathrm{Nd}$ & 0,24 & 40 & $\alpha-$ Cadinol & 0,37 & 0,18 \\
\hline & Bicyclic monoterpenes & & & 41 & Trans-Sesquisabinene Hydrate & $\mathrm{Nd}$ & 0,35 \\
\hline 15 & $\alpha$-Thujene & 3,83 & 4,19 & 42 & $\begin{array}{l}\text { (E)-3,7-Dimethylocta 2,6-dien- } \\
\text { 1yl } 3 \text { methylbutanoate }\end{array}$ & $\mathrm{Nd}$ & 0,18 \\
\hline 16 & D Alpha Pinene & 14,72 & 11,93 & 43 & (+/-) Trans Nerolidol & 2,02 & $\mathrm{Nd}$ \\
\hline 17 & Camphene & 0,51 & 0,20 & & $\begin{array}{l}\text { Total } \\
\text { sesquiterpenes }\end{array}$ & 6,79 & 3,31 \\
\hline 18 & Sabinene & 7,24 & 12,11 & & Others & & \\
\hline 19 & $\mathrm{~L}-\beta$-Pinene & 10,00 & 10,36 & 44 & $\begin{array}{l}4 \text { Methylpentyl 2- } \\
\text { Methylbutanoate }\end{array}$ & 0,32 & $\mathrm{Nd}$ \\
\hline 20 & 3 Carene & 0,72 & 3,11 & 45 & $\alpha$ - Limonene diepoxide & 1,77 & 1,86 \\
\hline 21 & 2 Carene & 0,71 & $\mathrm{Nd}$ & 46 & Hexanoic Acid Hexyl Esther & 0,25 & $\mathrm{Nd}$ \\
\hline 22 & Limonene Oxide Trans & $\mathrm{Nd}$ & 0,20 & & Total percentage others & 2,34 & 1,86 \\
\hline \multirow[t]{2}{*}{23} & Car 3 en 5 one & $\mathrm{Nd}$ & 0,21 & & & & \\
\hline & $\begin{array}{ll}\text { Total } & \text { percentage } \\
\text { monoterpenes } & \end{array}$ & 88,32 & 91,12 & & Not Identified & 2,56 & 3,71 \\
\hline
\end{tabular}

Table 6. Percentage composition of the essential oil of B. densiflora from Carpani

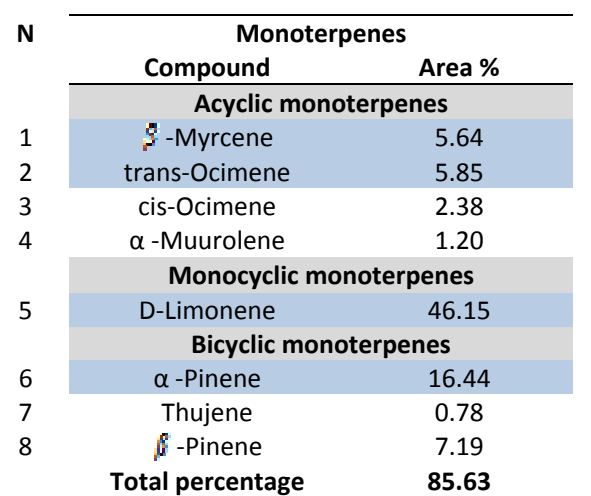

\begin{tabular}{ccc}
\cline { 2 - 3 }$N$ & \multicolumn{2}{c}{ Sesquiterpenes } \\
& Compound & Area \% \\
\cline { 2 - 3 } 9 & Hydrocarbon sesquiterpenes \\
10 & Caryophyllene & 0.57 \\
11 & Germacrene D & 0.50 \\
12 & Elixene & 1.16 \\
13 & y-Cadinene & 1.61 \\
& g-Cadinene & 4.60 \\
14 & Oxygenated sesquiterpenes \\
15 & 6-Epishyobunone & 0.99 \\
16 & Shyobunone & 3.00 \\
17 & tau-Muurolol & 0.88 \\
& $\alpha$-Cadinol & 1.08 \\
& Total percentage & 14.39 \\
\hline
\end{tabular}

Thus, in Baccharis densiflora, there was a predominance of monoterpenes, like in the major part of the species analyzed, representing $85,63 \%$ of the essential oil. In this case all compounds were identified, the main

Downloadable from: Revista Boliviana 
monoterpenes were: $\beta$-myrcene, trans-ocimene, D-limonene, and $\alpha$ - pinene, among them it was remarkable the presence of D-limonene which represents almost half of the essential oil $(46,15 \%)$. On the other hand, there was $14,39 \%$ of sesquiterpenes and the main were $\beta$-cadinene and shyobunone.

Making a global analysis of all Baccharis species under study, we conclude that their oils were composed mainly by monoterpenes, and the only exception was B. latifolia that had almost the same amount of sesquiterpenes. It was also observed that there were few compounds that are not terpenoids (Figure 1) with the exception B. tola from Carpani which contained 5.58\% of non-terpenic compounds.

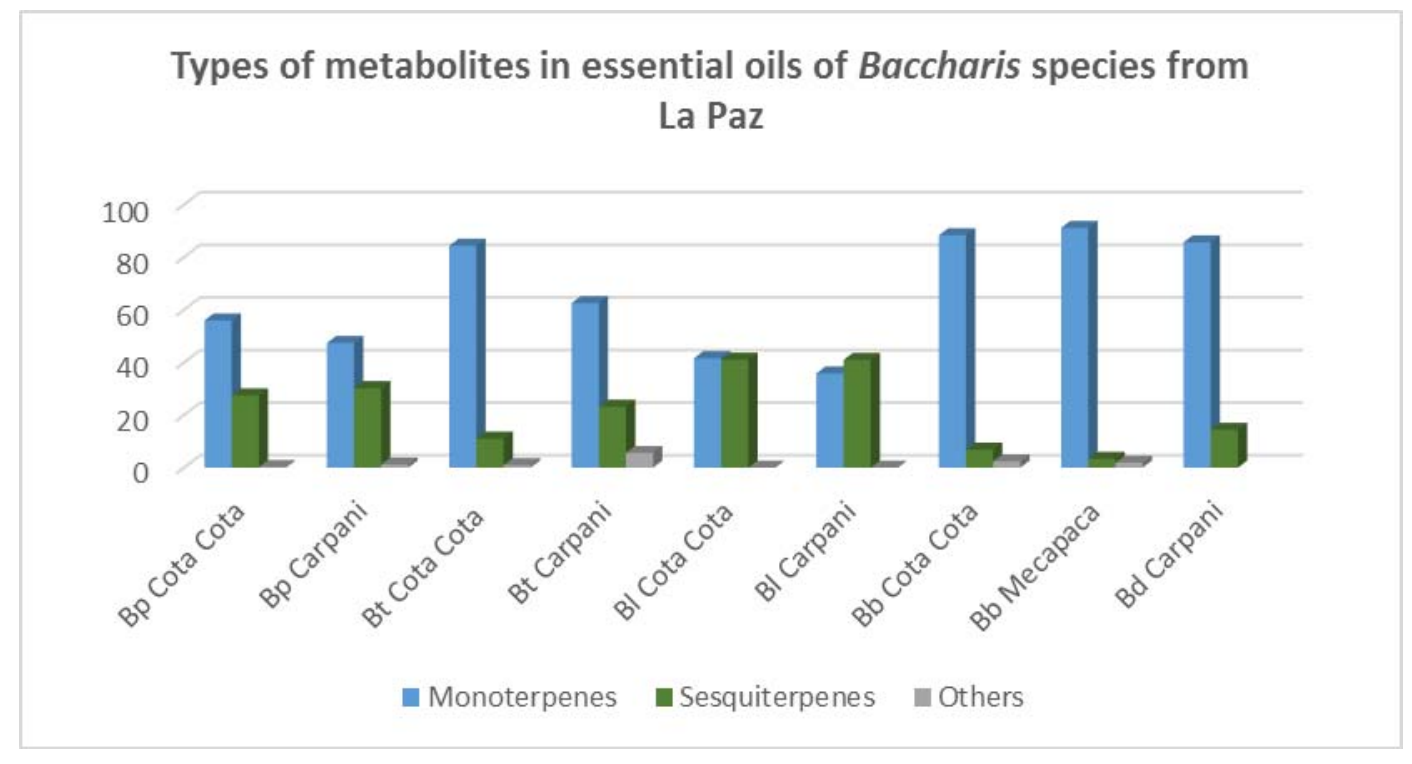

Figure 1. Types of metabolites in essential oils of Baccharis species from La Paz.

Figure 2 shows the types of monoterpenes and sesquiterpenes identified in the essential oils. In this graphic we can see similar profiles for the same species collected in two sites, but with some exceptions: Baccharis tola which clearly showed bigger quantities of hydrocarbon sesquiterpenes and lower quantities of monocyclic and bicyclic monoterpenes in Carpani than in Cota Cota. So, the environmental conditions in Carpani seem to stimulate the production of hydrocarbon sesquiterpenes instead of some cyclic monoterpenes in this species. There were also some differences in the production of sesquiterpenes in the samples of B. boliviensis, the sample from Cota Cota had more quantity of oxygenated sesquiterpenes than hydrocarbon sesquiterpenes, and the sample from Mecapaca had less oxygenated sesquiterpenes and more hydrocarbon sesquiterpenes.

Among the essential oils of the Baccharis studied, only that of B. latifolia has been previously studied (Loayza, 1995). In such previous study, the samples were collected in three localities of Cochabamba, Bolivia. The GC/MS profiles were similar with large quantities of sesquiterpenes and monoterpenes. They showed some similar major components, like $\alpha$-thujene and $\alpha$-pinene, but also there were some components very different in percentage, like germacrone $(41,85 \%), \gamma$-elemene $(10,29 \%)$ and D-limonene $(22,15 \%)$ in the essential oil from Montepunco $(2850$ m.a.s.l.), probably due to very different environmental conditions compared to the collecting sites of La Paz.

The analysis of the identified compounds in all five species studied, shows that there were some of them present in good quantities in almost all the essential oils studied, like the monoterpenes: $\beta$-myrcene, D-limonene, $\alpha$ thujene, $D-\alpha$-pinene, sabinene and L- $\beta$-pinene. Those compounds and others identified were isolated in other species and showed good pharmacological activities like $\beta$-myrcene, which showed anti-inflammatory, antiseptic, antispasmodic and analgesic properties [20-22] or D-limonene, which presented immunostimulant activity, apoptotic of breast cancer cells, and effectiveness against the bacteria that cause acne [23]. There are several studies about the antimicrobial activities of essential oils, showing that specific compounds cannot explain these properties due to complex mixtures of terpenes, mainly those with aromatic rings and phenolic hydroxyl groups [24]. Nevertheless, some of them have strong antibacterial activity proven like $\alpha$-pinene, $\beta$-pinene and D-limonene [25-27]. In addition, some others like $\alpha$-pinene, 3 -carene and $\beta$-cymene can inhibit acetylcholinesterase (AChE) showing a potential 
Silvia E. Ramos Paredes et al. RBQ Vol. 37, No.1, pp. 01-11, 2020

against Alzheimer [28]. Regarding sesquiterpenes, they were present in lower quantities but some of them were remarkable like $\alpha$-cubebene, which stimulates the production of chemokines (CXCL8 or IL-8) in human neutrophils [29], or trans-nerolidol, which was identified as antiulcer constituent from the essential oil of Baccharis dracunculifolia [30].

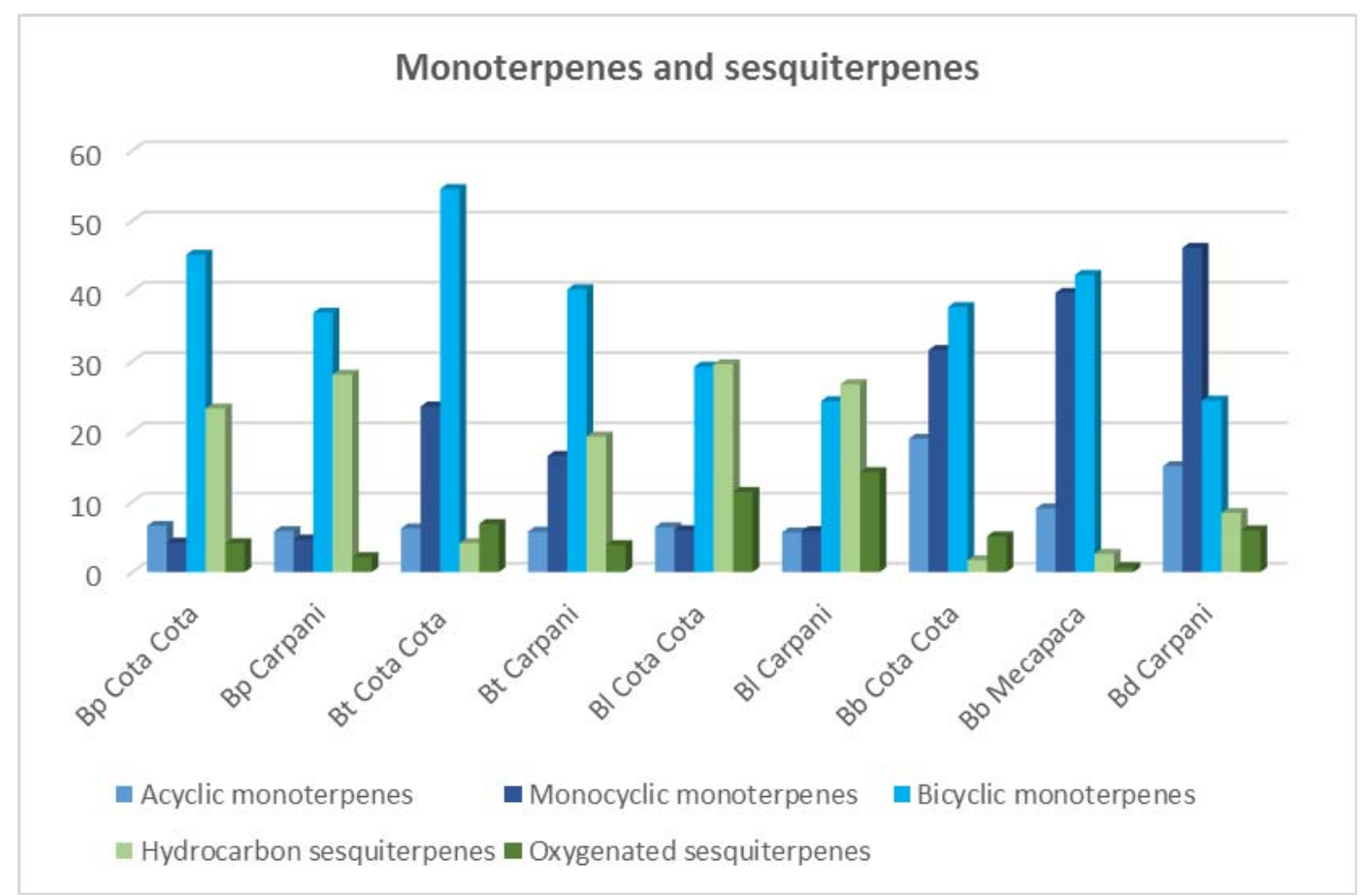

Figure 2. Types of monoterpenes and sesquiterpenes of essential oils of Baccharis species from La Paz<smiles>C=CC(=C)CCC=C(C)C</smiles>

$\beta$-Myrcene<smiles>C=CC=CCC=C1CCC1</smiles>

$\beta$-Ocimene<smiles>CC(=O)OCC=C(C)CCC=C(C)C</smiles>

Geranyl Acetate<smiles>C=C(C)[C@H]1CC=C(C)CC1</smiles><smiles>CCCCCC(C)c1cccc(C)c1</smiles><smiles>CC1=CCC2(C(C)C)CC12</smiles><smiles>CC1=CCC2CC1C2(C)C</smiles>

D-Limonene

$\beta$-Cymene $\alpha$-Thujene

D- $\alpha$-Pinene<smiles>C=C1CCC2(C(C)C)CC1C2</smiles><smiles>C=C1CCC2CC1C2(C)C</smiles><smiles>CC1C=CC2C(C1)C2(C)C</smiles>

Sabinene

4-Carene

Figure 3. Major monoterpenes identified in the essential oils of Baccharis species from La Paz 

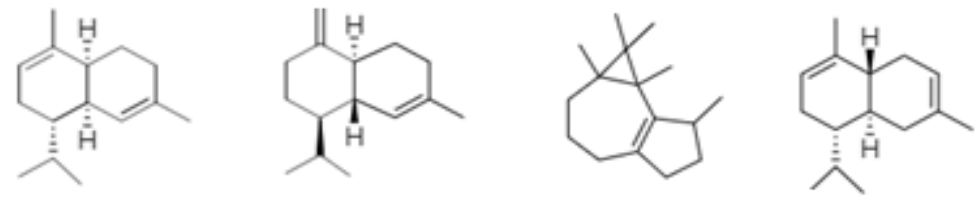

$\alpha$-Muurolene

y-Cadinene

1-(10) Aromandrene
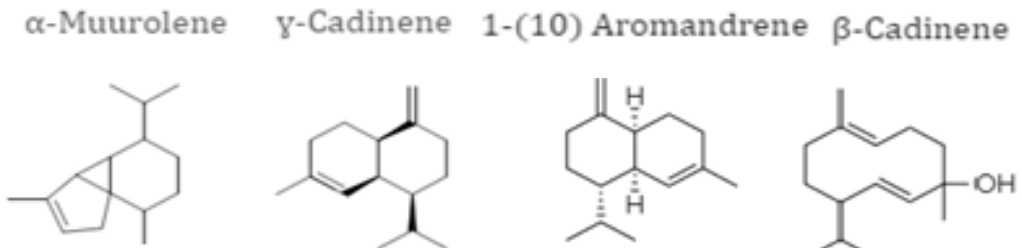

$\alpha$-Cubebene
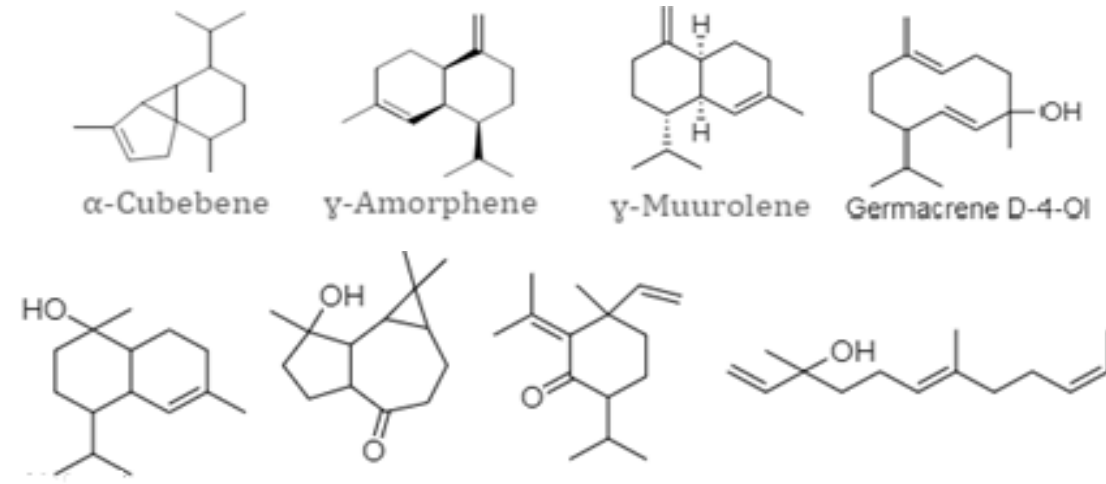<smiles>C=CC1(C)CCC(C(C)C)C(=O)C1=C(C)C</smiles>

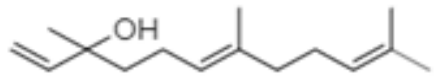

$\alpha$-Cadinol

Sphatulenol

Shyobunone

(+/-) Trans Nerolidol

Figure 4. Major sesquiterpenes identified in the essential oils of Baccharis species from La Paz

\section{EXPERIMENTAL}

\section{Plant material.}

The plant material was collected around the city of La Paz according to the details shown in table 1, so Baccharis boliviensis was collected from the community of Mecapaca (K 0606505 UTM 8157314) and University Campus of Cota Cota (K 0599543 UTM 8171528), B. densiflora of the Community of Carpani (K 0602947, UTM 8181212) and Cota Cota University Campus, B. latifolia of the Community of Carpani (K 0603029, UTM 8182407) and University Campus of Cota Cota, B. papillosa of the Community of Carpani and University Campus of Cota Cota, B. tola of the Community of Carpani and Cota Cota University Campus and finally B. densiflora of the Community of Carpani. The collected material was identified by Esther Valenzuela from JBLP (Botanic Garden of the National Herbarium of Bolivia), where samples of the collected specimens are deposited.

\section{Essential oils extraction}

The essential oil was extracted from $5 \mathrm{Kg}$ of fresh leaves of each species by hydrodistillation, the extraction was carried out for 3 hours, and the oil obtained was separated, dried with anhydrous magnesium sulphate and stored at 4 ${ }^{\circ} \mathrm{C}$ for further analysis by GC MS [31]

\section{GC/MS conditions for analysis}

$1 \mathrm{uL}$ of each oil was dissolved in $98 \%$ N-Hexane up to $2 \mathrm{~mL}$, then filtered with $0.2 \mu \mathrm{m}$ PTFE and subsequently analyzed in the GC-MS.

The composition of the oils was determined in a GC 2010 PLUS gas chromatograph coupled to a QP 2020 mass spectrometric detector, both SHIMADZU. The compounds separation was performed by a column of Sil MS RESTEK with 5\% diphenyl and $95 \%$ dimethyl polysiloxane $(30 \mathrm{~m} \times 0.25 \mathrm{~mm}$ and $0.25 \mu \mathrm{m}$ film thickness). The injection volume was $1 \mu \mathrm{L}$ at a total flow of $15.6 \mathrm{~mL} / \mathrm{min}$, and the column flow was of $0.60 \mathrm{~mL} / \mathrm{min}$. The temperature of the injector was $280^{\circ} \mathrm{C}$, the initial temperature was $40^{\circ} \mathrm{C}$, maintained for 2 min, subsequently the temperature was increased up to $210^{\circ} \mathrm{C}$ with a speed of $2{ }^{\circ} \mathrm{C} / \mathrm{min}$, for $5 \mathrm{~min}$, the ionization temperature used was of $230^{\circ} \mathrm{C}$ and the interface temperature was of $280^{\circ} \mathrm{C}$. 
The identification of the compounds was achieved by comparison of their mass spectra with a library data base (NIST14). Also mass spectra of the peaks were compared with published spectrometric data. Spectra were considered coincident if the similarity index was higher than $95 \%$. The percentage of compounds was calculated from the peak areas of the chromatograms [32].

\section{ACKNOWLEDGEMENTS}

We are indebted to SIDA Swedish Agency for the grant to Silvia Ramos as part of the project "Biomolecules of industrial and medicinal interest. Anticancer". We are also indebted with the funds IDH for UMSA, for the financial support of the project "Influence of meteorological and ecological variations in the production of secondary metabolites with phytotherapeutic and cosmeceutical potential of Baccharis sp., La Paz". Finally, we would like to thank Prof. Esther Valenzuela, Patricia Casillas and Juan Carlos Peñaranda from the JBLP, for the identification of the plant material.

\section{REFERENCES}

1. Verdi, L.G., Brighente, I.M.C., Pizzolatti, M.G. 2005, Gênero Baccharis (Asteraceae): aspectos químicos, econômicos e biológicos. Quim. Nova, 28(1), 85-94.

2. Abad, M.J., Bermejo, P. 2007, Baccharis (Compositae): a review update, Arkivoc, VII, 76-96.

3. Abad, M.J., Bessa, A.L., Ballarin, B., Aragon, O., Gonzales, E., Bermejo, P. 2006, Anti-inflammatory activity of four Bolivian Baccharis species (Compositae), J Ethnopharmacol., 103, 338-344.

4. Salcedo, L., Almanza, G.R. 2011. Uso de Baccharis latifolia (Chilca) en La Paz, Bolivia, Biofarbo 19 (1), $59-63$.

5. Enríquez, S., Quispe, R.E., Amurrio, P., Peñaranda, J.C., Calle, A., Orsag, V., Almanza G. R. 2018. Flavonoid contents in leaves of Baccharis latifolia, according to the type of leaf, and its dependence on the physicochemical properties of soils, Rev Bol Quim, 35(5), 146-154

6. Calle, A., San Martin, A., Melgarejo, M., Flores, Y., Almanza G.R. 2017. Evaluation of flavonoid contents and antibacterial activity of five Bolivian Baccharis species, Rev Bol Quim, 34(4), 111-121.

7. Escobar, Z., Flores, Y., Tejeda, L., Alvarado, J.A., Sterner, O., Almanza, G.R. 2009. Phenolic compounds from Baccharis papillosa subsp. papillosa, Rev Bol Quim. 26(2), 111-117.

8. Tarqui, S., Flores, Y., Almanza, G.R. 2012. Polyoxygenated flavonoids from Baccharis pentlandii, Rev Bol Quim. 29(1): 10-14.

9. Calle, A., Yupanqui, J., Flores, Y., Almanza, G.R. 2012. Flavonoids of Baccharis boliviensis, Rev Bol Quim. 29(2), 158-163.

10. Fabiane, K.C., Ferronatto, R., Dos Santos, A.C., Onofre, S.B. 2008. Physicochemical characteristics of the essential oils of Baccharis dracunculifolia and Baccharis uncinella D.C. (Asteraceae), Revista Brasileira de Farmacognosia, Brazilian Journal of Pharmacognosy, 18(2), 197-203.

11. Feresin, G.E., Tapia, A., Lopèz, S.N., Zacchino, S.A. 2001. Antimicrobial activity of plants used in traditional medicine of San Juan province, Argentine, J. Ethnopharmacol, 78, 103-107.

12. Jassim, S.A.A., Naji, M.A.A. 2003. Review: Novel antiviral agents: a medicinal plant preservative, J Appl Microbiol 95, 412-427.

13. Grassmann, J., Hippeli, S., Dornisch, K., Rohnert, U., Beuscher, N., Elstner, E.F. 2000. Antioxidant properties of essential oils. Possible explanations for their antiinflamatory effects, Arzneimittel-Forsch, 50, 135-139

14. Oliveira, R.N., Dias, I.J.M., Câmara, C.A.G. 2005. Estudo comparativo do óleo essencial de Eugenia punicifolia (HBK) DC. de diferentes localidades de Pernambuco, Rev Bras Farmacogn, 15, 39-43

15. Tavares, E.S., Julião, L.S., Lopes, D., Bizzo, H.R., Lage, C.L.S., Leitão, S.G. 2005. Análise do óleo essencial de folhas de três quimiotipos de Lippia alba (Mill.) N.E.Br. (Verbenaceae) cultivados em condições semelhantes, Rev Bras Farmacogn 15, 1-5

16. Malizia, R.A.; Cardell, D.A.; Molli, J.S.; Gonzalez, S.; Guerra, P.E.; Grau, R.J.J. 2005. Volatile Constituents of Leaf Oils from the Genus Baccharis. Part I: B. racemosa (Ruiz et Pav.) DC and B. linearis (Ruiz et Pav.) Pers. Species from Argentina, Essent. Oil. Res., 17(1), 103-106.

17. Concha, J., Cavieres, L.A., Sotes, G. J., Hernández, V. 2014. Essential oil composition of Baccharis linearis (Ruiz \& Pav.) Pers. and Baccharis paniculata DC leaves from Chile, American Journal of Essential Oils and Natural Products, 1 (4), 6-8.

18. Ferracini, V.L., Paraiba, L.C., Leitão Filho, H.F., Da Silva, A. G., Nascimento, L.R., Marsaioli, A.J. 1995. Essential Oils of Seven Brazilian Baccharis Species, Journal of Essential Oil Research, 7(4), 355-367.

19. Loayza, I., Abujder, D., Aranda, R., Jakupovic, J., Collin, G., Deslauriers, H., Jean, F. 1995. Essential oils of Baccharis salicifolia, B. latifolia and B. dracunculifolia. Phytochemistry, 38(2), 381-389.

20. Akono Ntonga, P., Baldovini, N., Mouray, E., Mambu, L., Belong, P., Grellier, P. 2014. Activity of Ocimum basilicum, Ocimum canum, and Cymbopogon citratus essential oils against Plasmodium falciparum and mature-stage larvae of Anopheles funestus s.s., Parasite, 21, 33-41

21. González-Zúñiga, J, González-Sánchez, H., González-Palomares, S., Rosales-Reyes, T., Andrade-González, I. 2011. Microextracción en fase sólida de compuestos volátiles en albahaca (Ocimum basilicum L.), Acta Universitaria, 21(1), 17-22.

22. Sajjadi, S. 2006. Analysis of the essential oils of two cultivated basil (Ocimum basilicum L.) from Iran, DARU Journal of Pharmaceutical Sciences, 14(3), 128-130.

23. Wright, K.L., Duncan, M., Sharkey, K.A. 2008, Receptores cannabinoides CB2 en el tracto gastrointestinal: un sistema regulador en estados de inflamación, Br J Pharmacol., 153(2), 263-70. 
ISSN 2078-3949 Rev boliv. quim. Electronic edition

24. Belletti, N., Ndagihimana, M., Sisto, C., Guerzoni, M.E., Lanciotti, R., Gardini, F. 2004. Evaluation of the antimicrobial activity of citrus essences on Saccharomyces cerevisae, Journal of Agricultural and Food Chemistry, 52, 6932-6938.

25. Magiatis, P., Melliou, E., Skaltsounis, A. L., Chinou, I.B., Mitaku, S. 1999. Chemical composition and antimicrobial activity of the essential oils of Pistacia lentiscus var. Chia, Planta Medica, 65, 749-752.

26. Filipowicz, N., Kamiński, M., Kurlenda, J., Asztemborska, M. 2003, Antibacterial and antifungal activity of juniper berry oil and its selected components, Phytotherapy Research, 17, 227-231

27. Silva, A.C.R.D., Lopes, P.M., Azevedo, M.M.B.D., Costa, D.C.M., Alviano, C.S., Alviano, D.S. 2012, Biological activities of $\alpha-$ pinene and $\beta$-pinene enantiomers, Molecules, 17(6), 6305-6316.

28. Miyazawa, M., Yamafuji, C. 2005, Inhibición de la actividad acetilcolinesterasa por monoterpenoides bicíclicos, J Agric Food Chem, 53(5), 1765-1768.

29. Guo, L.Y., Hung, T.M., Bae, K.H., Shin, E.M., Zhou, H.Y., Hong Y.N., Kang, S.S., Kim, H.P., Kim, Y.S. 2008, Anti-inflammatory effects of schisandrin isolated from the fruit of Schisandra chinensis Baill, Eur J Pharmacol, 591(1-3): 293-299

30. Klopell, F., Lemos, M., Sousa, J.P., Comunello, E., Maistro E.L., Bastos J.K., De Andrade S. 2014, Nerolidol, an Antiulcer Constituent from the Essential Oil of Baccharis dracunculifolia DC (Asteraceae), Zeitschrift für Naturforschung C, 62(7-8), 537-542.

31. Cyted. 1995. Manual De Técnicas De Investigación. Proyecto X-1 Búsqueda De Principios Bioactivos En Plantas De La Región, 8285 .

32. Adams, R.P., 2001, Identification of Essential Oil Components by Gas Chromatography/Quadrupole Mass Spectrometry, Allured Publishing Corporation, Carol Stream, Illinois, USA. 